INTERNATIONAL JOURNAL OF MULTidisciplinARY RESEARCH AND ANALYSis

ISSN(print): 2643-9840, ISSN(online): 2643-9875

Volume 05 Issue 02 February 2022

DOI: 10.47191/ijmra/v5-i2-06, Impact Factor: 6.072

Page No.- 284-286

\title{
Covid19 Pandemic Affected the Industry of Health and Wellness Tourism (Japanese Onsen)
}

\section{Joyce Say}

Graduate School of Asia Pacific Studies, Ritsumeikan Asia Pacific University, Japan

ABSTRACT: 'Health \& Wellness Tourism' and aims to plans to discover the principle effects of Coronavirus to the Wellbeing and Health the travel industry in Japan, and how the Japanese Wellbeing and Health The travel industry has figured out how to defeat the obstructions. With time elapsing, and understanding that the infection didn't vanish, society began to live with it. Social separating rules, better ventilation frameworks and required veil wearing began to be the new-typical. Particularly, in exercises like Japanese underground aquifer (Onsen), the utilization of Onsens by the Japanese is an extremely exceptional social and social peculiarity on the planet's Onsen culture. Be that as it may, because of the Covid19 pandemic emission, the Japanese onsens industry, which has been on the decrease for a long time, is being impacted more. What Japanese government have comes up is to re-began their organizations work, restricting the quantity of clients to try not to spread the contamination. ,. As more offices shut with an enormous shortfall, the Japanese government concocted an arrangement called "Go to Travel." This mission is tied in with getting up to half of the installment in the event that we reserve a spot for a home grown outing to Japan during the mission time frame through travel services and travel sites. That way it could help the wellbeing and health the travel industry to rise once more, and not impacted by the pandemic.

KEYWORDS: Health and Wellness Tourism, Japan, Covid19, Tourism Industry, Hot spring

\section{INTRODUCTION}

'Health \& Wellness Tourism' and aims to find out the main impacts of COVID-19 to the Health \& Wellness tourism industry in Japan, and how the Japanese Health \& Wellness Tourism industry has managed to overcome the obstacles. In 2020, one event disrupted the life of millions of people all around the globe. The Covid-19 pandemic, after one year is still creating issues and as for February 2021, more than 107 million people were infected with the virus (WHO, 2021). Different responses were taken in the country that got infected by the virus outbreak, such as national borders closure, lockdowns, state of emergency, use of face masks and social distancing rules. The unprecedented situation created major economic losses, and the travel bans that affected over $90 \%$ of the world population hit tourism industry the hardest (Gössling, Scott, \& Hall, 2020). The main response of Japan to the pandemic was the closure of international borders, as of February 2021, to 152 countries and regions of the world (Ministry of Foreigners Affairs, 2021) reducing the inbound tourism of 97, 7\% from 2019 (JBT Tourism Research \& Consulting Co, 2021). Various states of emergency have been put in place for 11 prefectures, without mandatory lockdowns or businesses closures in a method to keep Japanese economy afloat. With time passing, and realizing that the virus didn't disappear, society started to live with it. Social distancing rules, better ventilation systems and mandatory mask-wearing started to be the new-normal. In Japan, businesses re-started their work, limiting the number of customers to avoid spreading the infection.

In the report various activities, both physical and cultural, will be discussed and analysed to determine their importance on the wellbeing of the person, and how they were affected by the covid-19 pandemic. The wellness industry is estimated to be a 1.9 trillion dollar market where people travel because they want to maintain or improve their health condition. The main content of this paper will focus on the use of Onsen (Hot spring) under the Covid19 pandemic.

\section{THE HISTORIES OF JAPANESE ONSEN}

The Japan Onsen Association founded the organ paper "Onsen" in 1930, and as a medium for sharing various information and research results on Onsens, it actively promoted and encouraged the use of hot springs by tourists looking around. In addition, 


\section{Covid19 Pandemic Affected the Industry of Health and Wellness Tourism (Japanese Onsen)}

the development of tourist attractions, which prioritize success over medical and nursing use for citizens, will accelerate in accordance with the Onsen tourism strategy centered on the railway. In other words, modernization into 'commercial Onsens' takes place. Since the 1960s, Japan has entered a period of high economic growth. With the explosive increase in domestic travel and the attempt to expand the capacity of Onsens to accommodate them, traditional Onsens are gradually urbanized due to the expansion of lodging facilities and the discovery of new Onsens. The remarkable development of this period is the foundation of modern "tourist" Onsens. The most significant change in the history of Onsen culture in Japan is the production and consumption boom of the 'Onsen boom', especially open-air bath, which took place around 1985. As a result, large-scale accommodation facilities by large capital will be prepared, and open-air baths will be newly prepared in almost all Onsens (Kim, 2020).

The Japanese Onsens have been changed and developed in conjunction with the folk beliefs and recreational needs of the Edo period, and the growth of modern capitalism based on the basis of Touji. Of particular note in this process is the rich culture that Japan's Onsens have cultivated for a long time in order to survive as a box office, and accommodations for tourists who come to see the unique natural scenery of Onsens that out of active volcanic activity, as a health spa resort, there are a variety of cultures, such as the creation of the landscape, the arrangement of buildings conscious of the visitor, the daily life related to the Onsens, and giving meaning to various folk beliefs and oral traditions, customs and folk arts, etc. It can be said that it gives true value as a tourism product (Hwang, 2012).

\section{JAPANESE ONSEN RESTRICTION DURING THE COVID PANDEMIC}

The use of Onsens by the Japanese is a very special social and cultural phenomenon in the world's Onsen culture, as seen on TV in famous Onsen sites and newspapers and magazines. The unusual love of Onsens by the Japanese is already close to faith, and it can be seen as having a lot of arguments and reaching a blind level. Japan's Onsens sites were developed with the involvement of popular "tourism" that was different from the revitalization of Western medical and medical use, starting with treatment or therapy called Touji in Japanese. The activation of Onsens treatments called "Cuamiterhouse" or "Terme," which are covered by health insurance today, is deeply related to the history of using onsens based on Touji (Hwang, 2012). With the various restrictions and the social distancing regulations left a lot of individuals confined to their homes, resulting in social isolation that can lead up to mental problems such as anxiety and depression (Kato, Sartorius, \& Shinfuku, 2020). Such as, there is even a prospect that half of the Japanese onsens could disappear in the future." Japan's tourism industry has also contracted significantly since CoVID-19. Among them, the Japanese onsens industry, which has been on the decline for several years, is being affected more. For example, Nishi-Wakamachi, Iwate Prefecture has 10 onsens facilities co-run by villagers. The annual cost of maintaining ten onsens is 150 million yen. Villagers have shared the burden, and as the deficit has worsened recently, seven out of ten places have been put up for sale.

According to the Japan National Tourism organization (JNTO) announced on January 252021 , the number of foreigners visiting Japan in April 2020 was 2,900, down 99.9\% from the same month last year-on-year, can be seen in Figure 1.

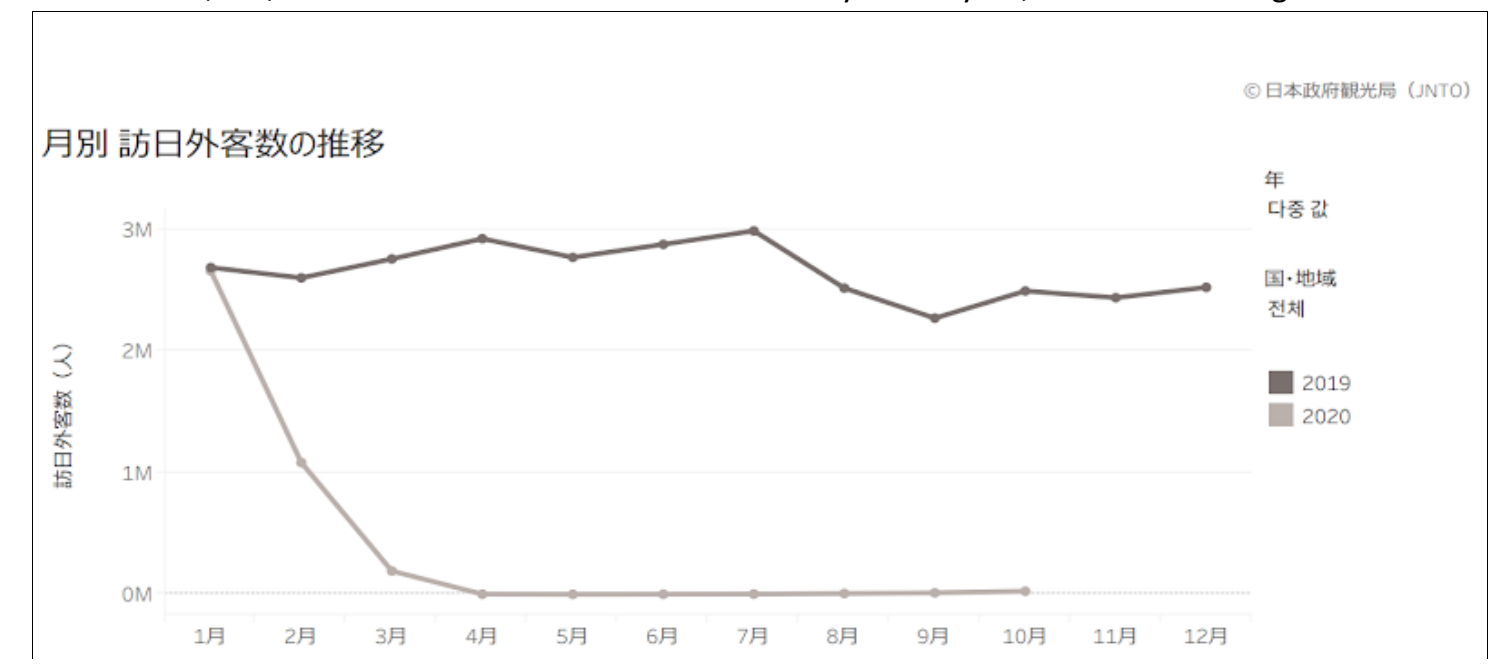

Figure 1: Japan National Tourism Organization, (2021)

This is the minimum since 1964 when JNTO began to tally the number of foreigners visiting Japan. Along with the number of foreigners visiting Japan, the number of hotels and other guests has declined sharply since February. At the "Tomorrow's Tourism Vision Conference to Support Japan" held in 2016, the goal was set at 40 million foreigners visiting Japan in 2020, but it is hopeless to achieve the goal due to entry restrictions and the postponement of the Tokyo Olympics due to the spread of CoVid-19. The 


\section{Covid19 Pandemic Affected the Industry of Health and Wellness Tourism (Japanese Onsen)}

spread of Covid-19 has dealt a major blow to the lodging industry around the world, but Japan's expectation of attracting more tourists and guests through the hosting of the 2020 Tokyo Olympics is particularly more affected.

\section{Solution of JaPANese Onsen Under The Covid PANDEmic}

As more facilities closed with a large deficit, the Japanese government came up with a policy called "Go to Travel." This campaign is about receiving up to half of the payment if we make a reservation for a domestic trip to Japan during the campaign period through travel agencies and travel websites. The upper limit of the amount of support is up to 20,000 yen per night. It's a maximum of 10,000 yen for one-day trips. $70 \%$ of the amount supported is given as a regional common coupon for travel discounts and $30 \%$ of the remaining purchases of local food, tourism facilities, or souvenirs (Go to トラベル事業とは, 2021). Only those who participate in the Go-to-Travel campaign (travel, accommodation, transportation, etc.) meet the absolute conditions of preventing the spread of new CoVID-19 infections (such as thorough condition checks on travellers and tightening measures to prevent congestion). For those who participate and use it as travellers, it is necessary to check and implement the [New Etiquette of Travel]. We should avoid large-scale banquets or group trips of young and elderly people who are prone to seriousness. Above all, it is important to think about and act on your own in order not to expand the infection.

\section{CONCLUSION}

To conclude, in the health and wellness tourism, these kinds of activities were chosen because of their traditional Japanese culture background. The covid-19 pandemic shifted their market to national residents or to online operations. These adjustments in the period of necessity showed how with new ideas they can be still practiced and implemented for the future. Although, the accommodation industry is still struggling due to the rapid drop in tourists due to the spread of Corona 19, but there is still a potential demand for foreign tourists, and various attempts are being made under the keywords "automation" and "non-contact" in the 2021 Tokyo Olympics. Not to be mention, some solutions were found. Virtual reality and digital implementation helped consumers and businesses in these times. The in-person contact shifted toward an internet-related one. Events started to take place online, allowing people to join them from the comfort of their houses. Where the, technologies such as automation were being developed to reduce the burden on employees in the lodging industry, which has been highly dependent on manpower since the past, and the reduction of fixed costs has emerged as an important task for each accommodation. In addition, robots are drawing attention again as a way to solve both fixed-cost cuts and Covid-19 measures at a time when Covid-19 measures have added tasks that have not been done so far. In the case of robots, it is also useful to reduce the risk of infection in a non-face-toface manner, which is expected to increase demand in accommodations in the future (Satoshi, 2020).

\section{REFERENCES}

1) Go to トラベル事業とは. (n.d.). Retrieved February 14, 2021, from https://goto.jata-net.or.jp/about/

2) Gössling, S., Scott, D., \& Hall, C. M. (2020). Pandemics, tourism and global change: a rapid assessment of COVID-19. Journal of Sustainable Tourism, 1-20.

3) Hwang, D. K., (2012). Hot Spring and Tourism Culture in Japanese Society, Japanese Culture Research, 42, 635-651.

4) JBT Tourism Research \& Consulting Co, (2021). Tourism Statistics. Retrieved Feb 14, 2021, from https://www.tourism.jp/en/tourism-database/stats/

5) Kato, T., Sartorius, N., \& Shinfuku, N. (2020). Forced social isolation due to COVID-19 and consequent mental health problems: Lessons from hikikomori. Psychiatry and Critical NeuroSciences, 506-507.

6) Kim, T. Y., (2020). An Improvement Plan for the Korean Wellness Tourism Industry Based on the IPA Analysis of KoreaJapan Hot Spring Tourism. Graduate School of Social Convergence at Sangji University, Gangwon-do

7) Ministry Of Foreigners Affairs. (2021). Border enforcement measures to prevent the spread of novel coronavirus (COVID19). Retrieved Feb 14, 2021, from https://www.mofa.go.jp/ca/fna/page4e_001053.html

8) Satoshi, S. (2020). Japanese hotels are preparing with robots. Retrieved February 11, 2021, from https://news.kotra.or.kr/user/globalBbs/kotranews/782/globalBbsDataView.do?setldx=243\&dataldx=183566

9) World Health Organization. (2021). WHO Coronavirus Disease (COVID-19) Dashboard. Retrieved Feb 14, 2021, from World Health Organization: https://covid19.who.int/

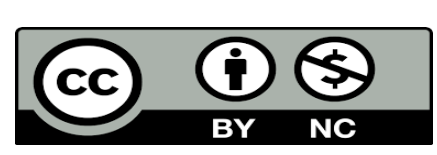

There is an Open Access article, distributed under the term of the Creative Commons Attribution - Non Commercial 4.0 International (CC BY-NC 4.0)

(https://creativecommons.org/licenses/by-nc/4.0/), which permits remixing, adapting and building upon the work for non-commercial use, provided the original work is properly cited. 